\title{
Poezja jako sztuka niegrzeczności
}

Piotr Michałowski 
nAPIS Seria X $2(0) 4$

\section{Piotr Michałowski}

\section{Poezja jako sztuka niegrzeczności}

$\mathrm{T}$ ak sformułowane równanie zawiera przynajmniej dwa założenia. Po pierwsze: istnieje korespondencja sztuki z pragnnatyką komunikacyjną i jakaś tych dziedzin jednokierunkowa przekladalność. Jeśli liryka jest swoistym ,teatrem mowy”, naśladıją̧cym rzeczywiste sytuacje komunikacji praktycznej, to również reguły dobrego zachowania w tych sytuacjach obowiązujące muszą przenikać do języka wiersza i w jego świat przedstawiony. Zresztą, że tak właśnie się dzieje, dowodów znajdziemy aż nadto — zwłaszcza w poezji nowoczesnej, chętnie odwołującej się do idiomu kolokwiahnego. Po drugie: istnieja pewne reguly niegrzeczności, tworzące symetrycznie odwrócony system reguł grzecznościowych, czyli swego rodzaju sauoir vitre à rebours. Założenie to również nie wymaga wiçkszych uzasadnień; świadectwa znajdziemy choćby w każdym poradniku, gdyż do wyeksponowania zaleceń dotyczących zachowań „wlaściwych”, to znaczy spolecznie akceptowanych, konieczne jest negatywne tho, a więc uboczne wskazanie na możliwe i niestety praktykowane zachowania oceniane jako niewłaściwe; są to przykłady albo wyraźnego naruszania zakazów, albo popełnianych niezręczności czy omylek.

\section{1.}

Kategoria grzeczności wydaje się mało przydatna w interpretacji literatury, ale wlaśnie jej niedostosowanie czy wręcz „niestosowność” jako narzędzia - zjawisko zresztą bynajmniej nie odosobnione we wspólczesnej refleksji literaturoznawczej - stanowi największą pokusę i zarazem wyzwanie. Jeśli w tytule stawiam mocną tezę, że poezja jest sztuką niegrzeczności, nie zamierzam twierdzić, iż jest nią zawsze i bezwyjątkowo, ani że poza niegrzecznością nie jest niczym ponad to; choć i tak szerokie ujęcie byloby prawomocne, jeśli przyjąć holistyczne rozumienie zachowania „grzecznego” jako zgodności z wszelkiego rodzaju normą, a więc także poprawnością językową i kanonem estetycznym. Po pierwsze chodzi bowiem tylko 
o pewne obszary poezji, gdzie pojawia się ,niegrzeczność” pojmowana wąsko, jako zachowanie kommikacyjne niezgodne ze skodyfikowanym (lub nie) pozaliterackim obyczajem, ale także o te sytuacje w poezji, gdzie jest ona dopuszczalna, czasem nieunikniona, a nawet konieczna. Po drugie - o incydenty manifestacyjnego naruszenia zasad savoir viure'u, o wypowiedzi, którym przypisać można złą intencję celowego popełnienia błędu, co w teorii aktów mowy wiąże się z kategorią „niefortumności” wypowiedzi, w etyce bywa naruszeniem tabu, w estetyce - przykładem zlego smaku, a zarazem odpowiada grzecznościowej kategorii negatywnej, zwanej fanx-pas. Zaznaczyć jednak trzeba, że nie ma pelnej ekwiwalencji między zestawionymi tu kategoriami stosowanymi w różnych sferach życia publicznego lub różnych ujęciach, toteż zwykle wyliczone zdarzenia pojawiają się wymiennie, choć często ich kwalifikacja do któregoś z tych porządków zależy jedynie od interpretacji lıb odmiennej perspektywy opisu zjawiska. Ale w poezji nakładają się co najnmiej trzy zespoły norm: językowych, retorycznych i obyczajowych; wydaje się zatem, iz przefiltrowanie poetyki immanentnej przez te trzy warstwy kultury byłoby antropologicznym powrotem do podstaw (choć niekoniecznie źródel) komunikacji i porozumienia. Nie chodzi jednak o tak głębinową geologię sensu, a jedynie próbę wydobycia z wypowiedzi pewnych złóż, których proweniencja i aspekt grzecznościowy są wyraźne.

Normy grzecznościowe, podobnie jak inne (estetyczne czy prawne) mają charakter historyczny, toteż nie można ominąć kwestii ich ewolucji i wynikającej stąd różnicy statusu analizowanych zachowań - innego w kontekście macierzystym utworu, innego we współczesnej pragmatyce odbioru. Dlatego przytaczane tu przykłady zostały dobrane w taki sposób, aby normy, do których się odnoszą, zachowywały i dziś swą aktualność, nie deformując obrazu uwarunkowań ówczesnej intencji autora i recepcji w konfrontacji z panującym obecnie stylem odbioru i przewidywalną reakcją dzisiejszego czytelnika. Chodzi więc o zasady trwałe i ponadczasowe, których naruszenie było i pozostaje nadal oczywiste. Warto również zwrócić uwagę na pewne konstanty, jakie wykazują poradniki dobrego wychowania. Adaptacja reguł o proweniencji salonowo-arystokratycznej do PRL-owskich realiów społeczno-ustrojowych czy ideologicznych miala na ogół charakter powierzchniowy; zmianie podlegały proporcje tematyczne, wạtki dotyczace jednych sytuacji wypierały inne, na przykład zamiast konwersacji na balu czy bankiecie pojawialy się przepisy prowadzenia zebrania rady zakładowej, organizacji partyjnej czy komitetu blokowego. Inwazja tych nowych zjawisk i próby ich normatywnego ujęcia widoczne sa — ze śladami cenzury prewencyjnej lub autocenzury jeszcze w wydawnictwach z lat osiemdziesiątych. Ale nawet przez te preferowane wątki „produkcyjne" przeświecają pewne starsze, przedsocjalistyczne zasady, które da się uogólnić jako niezmienne'.

Na przyklad w populannym poradniku. wydanymm, co znannienne, przez Instytut Wydawniczy Związkón Zawodowych: E. Pictkicwicz. Dobre olyezije. Warszawa 1987. 
2.

Ponieważ poezja należy do sfery zachowań językowych, najstosowniejszym kontekstem porównawczym i zarazem narzędziem do zbadania tych kwestii bẹdzie oczywiście poradnik dobrego tonu w praktycznej komunikacji werbalnej².

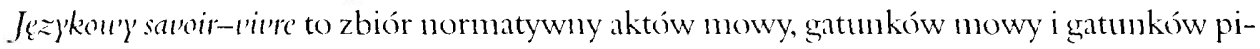
śmiennictwa użytkowego, zbudowany w oparciu o historycznie skrystalizowany obyczaj, zasady retoryki i erystyki. Obejmuje wskazówki dotyczące zachowań w typowych sytuacjach komunikacyjnych, zawiera formuly zalecane, niepolecane i wręcz zabronione: powitań i pożegnań, zwracania się do drugicj osoby, zawierania znajomości, sposobu rozpoczynania i kończenia rozmowy telefonicznej i listı, przeprosin, życzeń i pozdrowień, próśb, zaproszeń, przemówień, toastów i mów pogrzebowych, pisania życiorysu i podania, wreszcie - uwagi o sztuce rozmowy i dyskutuwania. Wszystkie te sytuacje w postaci różnie przetworzonej mogą się pojawić także w liryce jako ,teatrze mowy”, i rzeczywiście w niej występują, clıó w innych proporcjach gatunkowych; na pewno uprzywilejowane są formy komunikacji bezpośredniej i oralnej. choć technicznie bliższe literaturze pozostają gatunki piśniemnictwa użytkowego.

Wchodzimy (...) w obszar pewnej konwencji, a nawet więcej - konwenansów towarzyskich, obyczajów kulturowych. Sugerujemy jednocześnie podział na obyczaje dobre, godne pochwaly i niedobre, naganne ${ }^{3}$

- piszą autorzy językowego sau'oir-l'il'ré u. Choć w wielu micjscach swego poradnika dla uniknięcia schematyczności i banalu zalecają elastyczność stosowania gotowych formul (oczywiście tylko w pewnych dopuszczahnych ramach), odwohując się do inwencji twórczej czytelników, to latwo zauważyć, że intencje autorów tego rodzaju porad są bliższe klasycystycznym podręcznikom poetyki normatywncj, obejmującej nakazy, zalecenia, rady i zakazy, niz praktyce poezji nowoczesnej, a zwłaszcza jej odmianie awangardowej, która dąży wlaśnie do łamania regul i poszukuje takich zachowań stownych, które w konwencji się nie mieszczą. Innowacyjność w zakresie zwrotów grzecznościowych postrzegana jest wprawdzie jako dopuszczalna i możliwa, ale jedıak wiąże się z pewnynn ryzykiem i zagraża podstawom kultury, rozumianej jako system reguł koegzystencji spolecznej:

Można jednak wyobrazić sobie kontestatora, swoistego kulturowego naturystę, który nade wszystko cenić sobie będzie spontaniczność, naturalność swoich zachowań, sposobu bycia i reagowania, wyzwolonych od konwenansów towarzyskich i niepodleglych wobec wymogów kulturowej konwencji. Taki człowiek może się narazić na miano niewychowanego, czasem nawet barbarzyńcy kulturowegot.

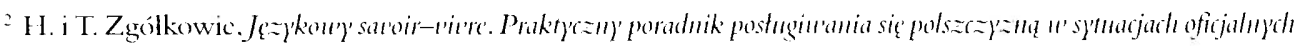
i tou'arz'skich, Poznań 1993.

"Ibidem, s. 7.

Illidem.
} 
Pozanormatywny margines zachowań zostal tu opisany w sposób lagodny, bliski tolerancyjnego przyzwolenia, ale też pośrednio napiętnowany, bo sama obrona granic normy zawiera już oczywisty akt wykluczenia - choć dokonany w sposób jakże subtelny i eufemistyczny, a więc w petni zgodny z propagowanym bon tonem. Z perspektywy roku 1993, kiedy cytowany poradnik się ukazał, trudno było jeszcze przewidzieć, że pierwotnie deprecjonująca etykietka „barbarzynícy” stanie się wkrótce dla poety najwyższą nobilitacją.

Konfrontując zespół norm grzecznościowych stosowanych w komunikacji z „niekomunikacyjnym" charakterem wypowiedzi poetyckiej, dostrzegamy więc przede wszystkim konflikt zasad. Prawem pierwszych zachowaí językowych jest konserwatyzm i redundancja (lub często sprowadzenie wypowiedzi do funkcji fatycznej - jak choćby w odsemantyzowanych zwrotach „dzień dobry”, „co słychać?”), natomiast prawem drugich jest rewelacja — zresztą zagrożona nieraz ryzykiem nieporozumienia.

Oczywiście, konflikt zostaje na użytek niniejszego przeciwstawienia laboratoryjnie wyostrzony, i łatwo można go złagodzić, a nawet zażegnać, przywołując kategorię różnicującą te dwie suwerenne sfery zachowań werbalnych: e t i o la c ję. Poezja to w końcu jedynie quasi-akt mowy, to wypowiedź cudzystowowa ${ }^{5}$, gdzie nawet największe ,zbrodnie” wyrażania korzystają z azylı imnej konwencji, którąjest licentia poetica. Dlatego wydawać by się mogło, że hasło ,niegrzeczność" trzeba od razu obezwladnić, ujmując w cudzysłów, sugerujący wlaśnie etiolację, a więc odtąd byłaby już mowa raczej o quasi-niegrzeczności, niegrzeczności obezwładnionej - w takim przynamniej stopniu, w jakim każda wypowiedź literacka uznana być może za akt quasi-komunikacji, wypełniony quasi-rzeczywistością powołaną do życia przez quasi-sądy". Jednak niekiedy niegrzeczność próbuje się jakoś przebić przez ten system zabezpieczeń literackiej konwencji, by odniéść rzeczywisty skutek perlokucyjny, na przykład w akcie prawdziwej obrazy kogoś lub czegoś - już bez niwelıjącego przedrostka „quasi-”. Niegrzeczność popełniona w wypowiedzi poetyckiej mimo cudzysłowowego filtra często zachowuje swą pierwotną moc illokucyjną, o czym przekonują najlepiej wypadki niefortunności czyli błędu zastosowania, choćby wtedy, gdy ktoś w towarzystwie przytoczy wulgarną ane. gdotę; znamy wypadki, gdy thumaczenie, iz był „to tylko cytat”, „tylko kawal”, sytuacji wcale nie ratuje.

1)oświadczenie historycznoliterackie uczy, że słowem poetyckim obrażano już wielo. krotnie w dzicjach (intencjonalnie lub nie), a dotknięte się czuly nie tylko umysły proste, alt i najbardziej światłe, którym znana była konwencja artystyczna, zwalniająca nie tylko autora ale i jego dzieło z odpowiedzialności za słowo. Sprawa zatem oczywista nie jest, i trzeba roz. ważyć zwłaszcza te wypowiedzi poetyckie, w których przywilej etiolacyjny bywal nadużywa ny i uchylany (niby poselski immunitet) — bądź w zamiarze twórcy, bądź jedynie w reakcj czytelnikil.

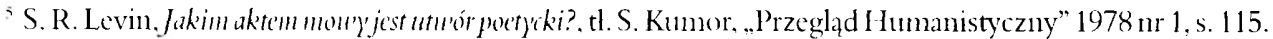

"R. Ingarden. O dziele literuckim. Badamia z pogramica ontologii, teorii jez)ka ifilozofii literatury. tl M. Turowica Warszawa 1988.
} 
Najczęściej zdarza siç to w obszarach poezji nowoczesnej, w jej wariancie awangardowym i postawangardowym, ale nie tylko, bowiem za akty niegrzeczności można uznać wszelkie wyłomy i zdrady popełniane wobec konwencji konnunikacyjnej, wykroczenia, które wywołują skandal, a niekiedy zmiany dhugofalowe, będące zwiastumami literackiego przełomu . Ale takie ujęcie wydaje się nazbyt szerokie, gdyż nie każdy „fałszywy krok” (by sięgnąć po kalkę językową francuskiego wyrażenia) wypowiedzi może odbiorcę urazić, a tu trzeba przyjąć, że chodzi o wyostrzenie whaśnie funkcji impresywnej. Po pierwsze więc przyjrzeć się warto tekstom dedykowanym lub adresowanym do osób rzeczywistych, polemikom literackim pisanym wierszem, które osobę adresata obejmują swoistym paktem referencjalnym, analogicznym do tego, który Lejeune przypisuje podmiotowi autobiografii ${ }^{8}$. Po drugie chodzi o niezależną od adresu obrazę gustu, niestosowność podjętego tematu, wreszcie - niezgodne ze zwyczajem ujęcie kompozycyjne i stylistyczne. O ile drugi wypadek może (ale nie musi) skutkować skandalem, to pierwszy wydaje się znacznie bardziej niebezpieczny, gdyż godzi bezpośrednio w odbiorcę konkretnego - nazwanego i wskazanego, bądź jedynie przywołanego implicite w rozmaicie skrojonych aluzjach: od klucza personalnego po różne odmiany parafrazy i zagadki. Adres może być czytelny dla wszysthich, bądź jedynie dla wskazanego adresata; w tym drugim wypadku z reguły chodzi o taktykę prowokacji wedle zasady „uderz w stól...".

\section{3.}

Najogólniej skonstatować można, że naruszenia normy popelniane są wobec: stylu języka (1); świata (2); adresata (3). Ale nie sposób tych wykroczeni (powiedzıny: metajęzykowych, referencjalnych i konatywnych) traktować calkiem rozlącznie, ponieważ wydaje się, że ostatecznie każde z nich adresata w jakimś stopniu dotyka - jeśli nie bezpośrednio (3), to whaśnie poprzez styl wypowiedzi (1) lub jej temat, gloszony pogląd na rzeczywistość czy system wartości (2).

Analizując dokładniej "metody” popełniania niegrzeczności, warto odwolać się do klasycznej retoryki, wyróżniającej pięć faz w budowic wypowiedzi: imeentio, compositio, elocutio, memoria i promuntiatio. Wydaje się, że decydıją tu trzy z nich: imeentio, czyli decyzja o tréści wypowicdzi, clocutio, czyli stylistyka oraz pronuntiatio, które wprawdzie oduosi się do sposobu artykulacji i bezpośredniego wykonania, obejmującego modulację głosu, gestykę i mimikę, ale i w tekście pisanym mogą pojawiać się sygnały modahności naddanej, sensów powstających wbrew slowom, i „przeciw słowom”, dzięki znajomości kontekstu; chodzi tu głównie o ironię. Niegrzeczność bowiem nie nusi być otwarta i wiązać się od razu z chanstwem, zastoso-

${ }^{7}$ O skandalach literackich pisali między innymi: M. Tranmor, Literamra i skendal, Katowice 2000); P. Micha-

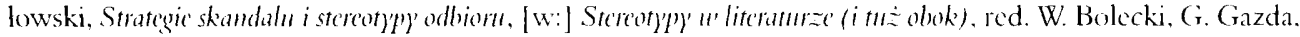
Warszawa $20(1) 3$.

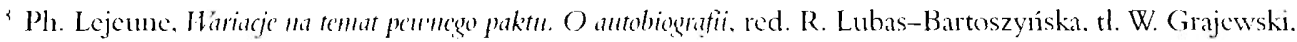
St. Jaworski, A. Labuda. R. Lubas-Bartoszyńska, Kraków 20011. 
wanien wulgaryzmów, wyzwisk i ekspresyjnych wykrzykników; przybiera także formy znacznie subtelniejsze, niekiedy zrozumiale jedynie dla wtajemniczonych, czasem wręcz będące szyfrem przeznaczonym dla wąskiego grona, a nawet zarezerwowanym wylącznie dla samej obrazanej wierszem jednostki.

Zakończenie slynnej polemiki Slowackiego z Mickiewiczem w Pieśni V poematu Benion'ski stwarza pozory nie tylko zawartego rozejmu, ale wręcz zgody z przeciwnikiem. Dystych wieńczący ostatnią oktawę jest pożegnaniem, które może nawet łudzić niè tylko jako wyraz szacunku, ale i przyjaźni:

Bądź zdrów! - a tak się żegnają nie wrogi,

Lecz dwa na stońcach swych przeciwnych - Bogi".

Taka wizja - nobilitująca adwersarza (ale przede wszystkim podmiot wypowiedzi) zamykać ma dzieje rywalizacji poetów. Oczywiście, można Słowackiemu uwierzyć, zwłaszcza kiedy się nie zna obyczajów bogów i obowiązującego w ich środowisku sanoir-vitre'u; jednak znajomość nitologii greckiej (chociaż Słowacki nawiązuje tu prawdopodobnie do wyobrażeń kosmogonicznych różnych kultur "1) wiarę w ich kurtuazję podważa i pozwala przypuścić raczej. że pod względem grzeczności Olimp sytuowal się na antypodach Wersalu. Sens formuly pożegnania zostaje raczej ironicznie zniwelowany przez ową boską analogię niż uprawomocniony obyczajem. Słowackiemu chodzi przeciez przede wszystkim o obronę suweremności własnych poglądów, o manifestację asertywności względem Pierwszego Wieszcza, który chciał być jedynym i nie dopuszczał myśli o jakiejkolwiek konkurencji, czyli politeizmie na emigracyjnym Parnasie. Totez awansowanie Mickiewicza na Boga jest w istocie degradacją przeciwnika, skoro miast uznać go za jedynego atıtor poematu opowiada się otwarcic za „wielobóstwem” i projektuje partnerską równorzędność adwersarza z własną osobą. Jeśl natomiast przywolać szerszy kontekst, obejmujący sześć wcześniejszych wersów cytowane. oktawy, deprecjacja przeciwnika staje się wyraźna:

\section{(...) Bądź zdrów, wieszczu!}

Tobą się koríczy ta pieśń, daw n y Boże.

Obmyłem twój laur, w słów ognistych deszczu,

I pokazatem, że na twojejj korze

Pęknięcie serca znać - a w liści dreszczu

Widać, że ci coś próchno duszy porze.

$$
\text { [podkreśl. moje - P. M.] }
$$

Z jednej strony Słowacki podkreśla zaszczytne (bo finałowe) micjsce przydzielone Mic kiewiczowi w poemacie, z drugiej, prócz gorzkich slów krytyki, pisze słowo „wieszcz” ma! literą, a boski status poety uznaje za nieaktualny. W tym kontekście lakoniczność dwukrotne 
go zwrotı pożegrnalnego „bądź zdrów!” sygnalizuje co najmuiej chłód i oziçbłość, jeśli nie wrogość $^{11}$. Gdyby przelożyć go na powszechniejszą dziś praktykę otwartości w wyrażaniu stosunku do antagonisty, zwrot brzmialby po prostu (w wersji ocenzurowancj): „Spadaj!”.

\section{4.}

Retoryka przewiduje trzy cele wygłaszancj mowy: docere, delectare i monere. W akcie popelniania niegrzeczności trzeci z nich, poruszenie sluchacza, wydaje się konieczny i nadrzędny wobec dwóch pozostałych, które mogą współwystępować z nim wymiennie. Poruszenie słuchacza (zarówno emocjonalne, jak perswazyjne) jest bowiem celem pierwszym, choć zazwyczaj tylko pośrednim, który służy dopiero w dalszej fazie zabawie lub dydaktyce (poznaniu). Różne motywacje i cele poetyckiej „nicgrzeczności” ułożyć można w gradację, która jak się zdaje — odpowiada stopniom jej nasilenia. Są to:

\section{1. asertywność;}

2. kontestacja;

3. prowokacja.

Trzeba zatem odróżnić intencje: defensywną, kontrofensywną i ofensywną; potrzebę obrony od aktu agresji; bunt od pożądania władzy. Wprawdzie często współwystępują one, tworząc łańcuch przyczynowo-skutkowy, jednak nieshusznie we wszystkich tych zachowaniach sklonni jesteśmy dostrzegać przede wszystkim prowokację; wiele bardzo ostrych i nawet najbardziej niegrzecznych słów ma bowiem charakter obronny jako gwałtowna reakcja na zewuętrzne (zwykle w utworze przemilczane) nakazy, naciski, namowy. Postawę asertywną najlepiej chyba określa poetycki termin Marcina Świetlickiego, który zresztą zrobił pewną karierę i niewykluczone, iz zagrzeje miejsce w słowniku języka polskiego: „nicprzysiadalność". Wszystkie wulgarne ozdobniki towarzyszące tej manifestacji można już pominąć.

Niekiedy asertywność obejmuje nie socjologiczny wymiar jednostki, ale jej psychologię, gdy zamiast presji społecznej pojawia się wewnętrzıa pokusa koniunkturalizmu. Zniny wiersz Andrzeja Bursy Sobota rozpoczyna się dywagacjami o możliwościach spędzenia wolnego czasu, a jedną z nich jest napisanie czterech reportaży o perspektywach małych miasteczek. Nagłe opamiętanie każe jednak tę pokusę odrzucić, i to możliwie najgwaltowniej, by więcej nie powróciła - jako potrzeba obca czy wręcz zaraźliwa choroba zagrażająca autonomii jednostki; stąd zamiast „daj sobie spokój z malymi miasteczkami” pojawia się trzykrotnie zwrot, którego powtórzyć tu nic wypada, jeśli pozostać w jakichś granicach normy grzeczności w artykule o niegrzeczności.

Ale u tego samego poety pojawiają sį̣ też znacznie poważuiejsze pretensje do świata, i to zaadresowane - jak się wydaje - aż nazbyt precyzyjnie. Wiersz Zażalenic, którego podmiot-petent posiada personalia autora (wymienia swe nazwisko: Andrzej Bursa) rozpoczyna się tak:

" H. I T. Zgólkowic. op. cit.. s. 28-29. 
Panie ministrze sprawiedliwości...

pan mnie obraża?

Sformutowanie apostrofy wydaje się zgodne z norma pisma urzędowego, ale z pewnością jakimś aktem niegrzeczności są małe litery w nazwie stanowiska adresata. Oczywiście nietypowe jest juz pierwsze zdanie, zawierające otwarcie wyrażony zarzut, a dalej następuje materiał dowodowy świadczący o prześladowaniu autora przez caly aparat władzy, który w schizofrenicznie wyolbrzymiającej wizji skierowany jest wlaśnie przeciw niemu jako jednostce. To skowyt zgnębionego obywatela na granicy paranoi, gdyż całe zło spotykające jednostkę zostaje przypisane instytucji państwa - i trafnie, i nietrafnie, ponieważ krytyka zaangażowana miesza się tu z urojeniami jednostki bezsilnej lub ubezwlasnowolnionej, podobnie jak w dużo późniejszej Apelacji Jerzego Andrzejewskiego. Odstępstwem od zasad — ale raczej od procedury urzędowej niż norm grzecznościowych, bo ton calego listu pozostaje w zasadzie uprzejmy, a w każdym razie nieobraźliwy - jest niefortumność adresu: zażalenie na kogoś powimno się kierować nie do niego samego, ale do instancji odeń wyższej, bezpośrednio nadrzędnej. W tym wypadku absurd wysyłania skargi na państwo do jego przedstawiciela wynika właśnie z braku w ustroju totalitarnym takiej instancji odwolawczej jak na przykład funkcjonujący dziś Rzecznik Praw Obywatelskich czy Trybunał Stanu. Niestosowność (omylka) adresu organizuje tu zatem podtekst i cliyba implikuje sens nadrzędny.

To zresztą rzadki przypadek precyzyjnego określenia nadawcy i adresata, wynikający z nawiązania do wskazanego w tytule gatunku użytkowego. Niestety, przyktad mało przekonujący, gdyż zawiera motyw paranoi podmiotu-bohatera.

\section{5.}

Wypowiedź liryczna zbliża się najczęścicj raz do wzorca wypowiedzi bezpośredniej, nadanej „twarzą w twarz”, kiedy indziej telefonicznej, albo do listu; jest komunikatem jednostronnym, ale zawierającym potencjal dialogu. To głos, który odzywa się nagle i równie nagle milknie w zamykanej książe. Głos kierowany nie do konkretnego adresata ani do wszystkich, ale do każdego, kto zechce doń dotrzeć. Ta sytuacja nie znajduje analogii w komunikacji praktycznej. Językowy sa'oir viı're nakazuje nadawcy przy nawiązywaniu pierwszego kontaktu a więc i znajomości, najpierw dokonanie prezentacji swej osoby. W literaturze formalnie tym aktem jest podpis autora, natomiast liryczne ,ja" wymaga dopiero rekonstrukcji, dokonywa. nej w toku interpretıjącej lektury. Ale ta półanonimowość nadawcy nie wydaje się istotna gdyż nie może spowodować żadnej niegrzeczności. Niebezpieczeństwo wiąże się natomias z anonimowością adresata i wynika z napięcia między odbiorcą wirtualnym a konkretnym pojawia się tam, gdzie mamy do czynienia z liryką inwokacyjną bądź pojedynczą apostrofą wszędzie, gdzie zostaje użyty zaimek ,ty”, gdyz ten, choć pozostaje potencjalny i anonimow (deiktycznie pusty), zawsze pośrednio i ostatecznie zwraca się do czytelnika rzeczywistege

12 Wszystkic wicrsze Andrzcja Bursy cyt. za: A. Bursa, ('tur') u'ierszem i prozq, wyb. opr. i wst. St. Stanuch, Kra ków 1982. 
W miejscu takiej apostrofy etiolacyjna skorupa ochronna tekstu najbardziej narażona jest na przebicie. Dlatego bywa ono najdogodniejszym micjscem na wszelkiego rodzaju akty prowokacji. Subtelne zalożenie, że tekst literacki wostatecznej instancji jest przeznaczony d l a k o goś, a nie d o kogoś skierowany ${ }^{13}$, niewiele znaczy wobec wieloznaczności jednego „ty”, obshugującego wszystkie figury odbiorcy - wewnątrz - i zewnątrztekstowe.

Łatwo prześledzić ten mechanizm odbioru na zastosowanym w rozmowie praktycznej dowolnym „obraźliwym” cytacie poetyckim — pod warunkiem, że nie będzie należal do „słów skrzydlatych”, a więc latwo rozpoznawalnych, jak na przykład „Precz z moich oczu!”. Spróbujmy się zwrócić do kogoś tymi słowami:
Mówię do ciebie, bydlę
i do ciebie, bydlę.
Do ciebie - skoro nie rozumiesz,
do ciebie - skoro masz mnie zabić
i wstępnie wtykasz we muie palce

Wiersz Marcina Świetlickiego Od dzisiaj wojna jest niegrzecznością wyraźnie defensywną, wynikającą z poczucia zagrożenia ze strony być może całego świata, bądź tylko jego stref zmilitaryzowanych; trudno jednak określić zakres tego zbiorowego adresata (chodzi jednak nie tyle o grupę, ile kilka osobnych jednostek), gdyż wyzwiska są ciosami, które podmiot wypowiedzi rozdaje po omacku. Zakres odniesienia „ty” pozostaje w tej apostrofie nieokreślony; z kontekstu wynika, iz chodzi albo o obserwowanego w telewizorze kosmonantę Hermaszewskiego, albo sprawców i wykonawców stanu wojennego, albo całe spoleczerístwo, o hipostazę historii, wreszcie - Boga.

Ciekawym kontekstem tego zagadnienia jest książka Dariusza Pawelca, analizująca różnego typu ataki przypuszczane na odbiorcę, ksiązka w której jednak problen agresji werbalnej ujęty został w sposób osobliwie zawężony, z pominięciem właśnie tego, co wydaje się tu najważniejsze - retoryki obrażania ${ }^{15}$. Badacz ten, wspierając się stanowiskiem Janusza Sławińskiego, który rozdziela „poziom literackiej reprezentacji” od .poziomu oddziaływania i recepcji" ", dopuszcza przenikalność między wnętrzem a zewnętrzem utworu jedynie $\mathrm{w}$ aspekcie związków intertekstualnych ${ }^{17}$. Natomiast wsponmiane przeze muie incydenty „uchylenia etiolacji”, polegające na skumulowaniu ról odbiorcy wirtualnego i konkretnego, znajdują jakieś umocowanie w poglądzie Janusza Lalewicza ${ }^{18}$.

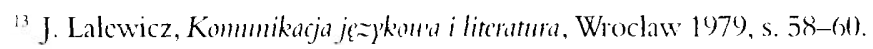

" M. Świctlicki, Zimme kraje 2. Kraków 1995.

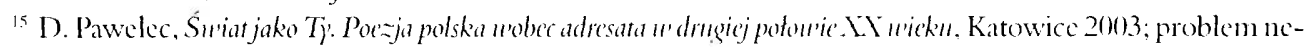

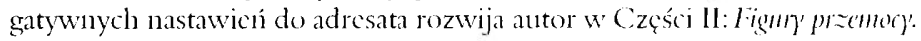

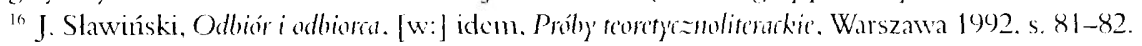

${ }^{17}$ D. Pawclec, op. cit.. s. 21-23.

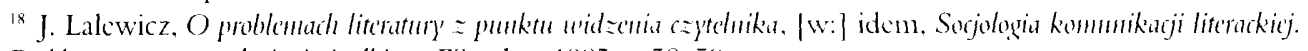
Probleny rozpouszcchnicnia $i$ odbion. Wrochaw 1985, s. 58-59. 
Jednym z nieuniknionych kontekstów analizy sytuacji owych przebić przez skorupę etiolacyjni do osoby odbiorcy rzeczywistego jest pytanic o komunikatywność i styl recepcji, a przede wszystkim o fortumność adresu i spotkania czytelnika z tekstem. Językowy savoir vivre zakłada, że wybierając treść rozmowy z nieznajomym, powinniśmy uwzględnić jakąś wspólnotę tematyczną i dostosować - zgodnie z naszą wiedzą o potencjalnym interlokutorze sposób wyrażania: jeśli znamy środowisko zawodowe lub towarzyskie przyszlego rozmówcy, wybór tematu i stylu nie powinien sprawiać trudności ${ }^{19}$. W kommikacji literackiej domniemana charakterystyka odbiorcy musi być tak ogólna, że nieprzydatna: niezależnie od założeń i marzeń autora, będzie to każdy, kto potrafi czytać w danym języku. Tym samym utwór może urazić znacznie większą liczbę osób niż zakłada intencja autora - a to problem znacznie poważniejszy. Zdarza się, że autor, zdając sobie sprawę z nieokreśloności figury adresata w tekście, czuje się calkowicie bezkarny, co wykorzystuje do prowadzenia swobodnej gry zakresami adresowych odniesień .ty” i przemyślnie projektowanej przez siebie pulapki obrazy.

Andrzej Bursa jedną ze swych najbardziej znanych miniatur poetyckich Pantofelek zbudowal na hatwo rozpoznawahym schemacie, bliskim konceptom barokowym: najpierw zastosowal gradację wartości, by potem w rozumowaniu dokonać nagłego zwrotu z użyciem silnej antytezy.

1)zieci są milsze od doroslych
zwierzęta są milsze od dzieci
mówisz, że rozumując w ten sposób
muszę dojść do twierdzenia
ze najmilszy jest pierwotniak pantofelek

no to co

milszy mi jest pantofelek

od ciebie ty skurwysynit

Kiedy czytelnikowi już minie szok wywołany efektowną, skandalizującą puentą, musi powstać wątpliwość, kto ma być docelowym odbiorcą tej niewątpliwie obraźliwej oceny i jak: jest zasięg projektowanego „ty”. Czy chodzi o atak na każdego dowolnego czytelnika (płc męskiej), czy może tylko na pewną grupę odbiorców, może właśnie tych, którzy byliby skłonni zanegować zaproponowaną logikę aksjologii? A może chodzi o jakąś osobę konkretną, któ. ra przypadkiem rozpozna się w czytanym tekście? Czy jest to zatem słowny zanach na czlo. wieczeństwo, skrajna negacja antropocentryzmu, czy też prywatne porachunki? Czy „ty” sy tuıje się poza osobliwym systemem aksjologicznym, czy też staje się nim ktoś wlaśnie dlate go, że nie chce uznać forsowanej tu skrajności wartościowania?

11. i T. Zgólkowic. op. cit. s. $5+-55$. 
Analiza logiczna ujawnia jednak, że siła kontrastu nic jest w tym wierszu tak wielka, jak sugeruje bulwersująca anty-antropocentryczna puenta, gdyż trzeba zestawić ze sobą szereg nierówności:

$$
\text { dorośli }<\text { dzieci }<\text { zwierzęta }<\text { pantofelek }
$$

oraz

$$
\text { pantofelek > ty. }
$$

Wówczas „ty” może być zarówno dzieckiem, jak i dorosłym. Tym samym obraza skupia się na obiekcie nazbyt dowolnym, nijak nieokreślonym - poza ogólną klasą człowieka. Ostateczny efekt retoryczny nie dorównuje więc sile ekspresji językowej (jeśli za istotne wzmocnienie wypowiedzi uznać użyty wulgaryzm), a tym samym w świecie manifestowanych wartości żaden przewrót się nie dokonuje.

\section{6.}

Zdecydowanie slabsze są akty obrazy formulowane narracyjnie i w trzeciej osobie. Mou'a pogrzelou'a Andrzeja Bursy to przytoczenie typowego przemówienia nad grobem, sławiącego zasługi osoby zmarłej. Ten quasi-cytat pozostaje nienaruszony jakąkolwiek interwencją niegrzeczności, a polemiczny sens wytwarza dopiero kontrastowa puenta:

(chodzi o asenizatora utopionego przypadkowo w gównic)

Jest to więc komentarz „cichy”, jako że następuje poza sytuacją obrzędu żałobnego, i trzeba go wiązać nie tyle z niegrzecznością, ile z niedyskrecja. Demaskuje bowiem konwencję nakazującą o zmarłych nie tylko mówić dobrze, ale i wyolbrzymiać ich zaslugi. Podniosły styl okolicznościowej apoteozy w najmniejszym stopniu nie zależy od charakteru postaci nicboszczyka opisywanego w mowic wygłoszonej nad jego grobem, ponieważ konwencja zakłada, że forma ta przysłıguje z urzędu po śmierci każdemu, niezależuie od jego rzeczywistych zasług. Niestosowność pozaobrzędowego komentarza polega więc na zaznaczeniu rozdźwięku między konwenansem a prawdą i obnaża fałsz rytuału.

Ingerencji aktu niegrzeczności w świat przedstawiony dokonuje Bursa natomiast w Dyskursie z poetq, wierszu, relacjonującym jakąś wcześnicj odbytą z udzialem ,ja" rozmowę o poezji, której głównym wątkiem był dylemat: "Jak oddać zapach poezji”, zainspirowany prawdopodobnie sonetem Baudelaire'a Correspondance:

Są aromaty świeże jak ciała dziecinne,

Dźwięczne i niby łąki — zielone; są inne.

Bogate i zepsute, silne, tryumfalne, 
Które się rozwiewają w światy idealne,

Jak ambra, benzoina, jako piżma wonie,

Gdzie duch przenika zmysty i wzajem w nich tonie ${ }^{211}$.

Nie wiadomo, czy relacjonowana w utworze Bursy debata miała podobny przebieg, ale zapewne rozważano w niej właśnie subtelności woni odpowiadające słowom. Z pewnością natomiast jej zakończenie było niefortumne, lecz zarazem przyniosło pewne rozstrzygnięcie:
rozmawialiśmy w jak najlepszej symbiozie
aż do chwili gdy powiedziałem:
.,wynieś proszę to wiadro
bo potwornie tu śmierdzi szczyną"

Wiersze Bursy chętnie operują dysonansem stylistycznym, a do uprzywilejowanych figur należą w nich z pewnością klimaks i antyklimaks. W tyn wypadku brutalne przejście od wznioslej abstrakcji do przyziemnego konkretu jest zarazem pewnym przypadkowym wnioskiem rozważań estetycznych: wyraziście przeciwstawia piękno prawdzie. Trudno jednak ocenić, czy dostrzeżenie pewnej „prawdy” burzy konwenans, gdyż dyskusja nie powinna poruszać się na poziomie rytuału - tak jak nowa pogrzebowa; tu chodzi raczej o uczciwość argumentacji w prowadzeniu sporu. Warto więc odwołać się do erystyki i spośród chwytów skodytikowanych przez Arthura Schopenhauera wskazać pozycję 29. - „dywersję", polegającą na tym, że kiedy jedna ze stron sporu przegrywa, zaczyna mówić o czymś zupełnie innyın, zachowując pozór, iz trzyma siç tematu ${ }^{2 !}$. Niekoniecznie jednak w finale dyskusji o poezji trzeba dostrzegać zastosowanie argmmentacji nieuczciwej. Wiersz zresztą kończy się jeszcze jedną puentą, która próbuje wyjaśnić, zalagodzić i zaznaczyć dystans do tamtego, „niegrzecznego" finału dyskusji:

możliwe że to było nietaktowne ale już nie mogłem wytrzymać.

Wskazuje to raczej na chwyt 33., który podważa teorię za pomocą przykładu pochodzącego z praktyki ${ }^{22}$. Puenta wygłoszona juz poza konsytuacją streszczonego w wierszu dialogu adresowana jest do czytelnika, i trudno ją uznać za usprawiedliwienie (przeprosiny tym bardziej nie wchodzą w grę, gdyz powinno się je kierować do byłego rozmówcy, a nie do osób trzecich); jest raczej przedłuzeniem i przeniesieniem debaty o poezji ze sfery świata przedstawio. nego na poziom dialogu z czytelnikiem, a więc daje się odczytać jako swego rodzaju manifes estetyczny.

20. Ch. Bandelaire. Kin'iaty zha, wyb. M. Leśnicwska i]. Brzozowski, Kraków 1990; w cytowanym przekładzi Antonicgo Langego sonet zostal zatytulowany Odd

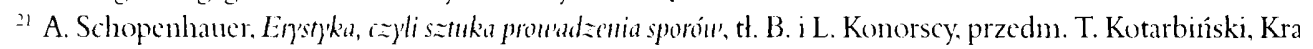
ków 1984, s.7t.

$\therefore$ Ibidem, s. 84-85. 
Ostatni przykład pokazuje sytuację najbardziej typową i oswojoną przez konwencję: niegrzeczność popelniona w poezji nie eksploduje tak mocno jak w życiu towarzyskim, ale z pewnością ma większy zasięg i trwalsze oddzialywanic - whaśnie przez to, że przestaje być niegrzecznością, a staje się poetyckim sensem. Wyizolowana z okoliczności wypowiadania, z ukladu deiktycznego, poddaje się wielokrotnej i wielostromnej interpretacji. Niezależnie od genezy, wypowiedź pierwotnie okazjonalna oraz indeksalna zastyga w znak autonomiczny, w czystą potencjalność symbolu. Tym silniej znaczy, in bardziej argumenty ad personam przekształca w ad rem; im mnicj skierowana jest przeciw osobie, a bardziej zbliża się „k" rzeczy" zresztą zgodnie z etymologią słowa „grzeczność”. 